\title{
TRUNK BIOMASS ESTIMATION BY DIFFERENT METHODS IN A SUBTROPICAL FOREST
}

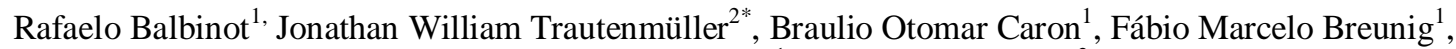 \\ Fernanda Raquel Lambrecht ${ }^{1}$, Sérgio Costa Júnior ${ }^{2}$ \\ ${ }^{1}$ Universidade Federal de Santa Maria, Frederico Westphalen, Rio Grande do Sul, Brasil. rafaelo.balbinot@gmail.com; \\ otomarcaron@yahoo.com.br; fabiobreunig@gmail.com; fernanda.lambrecht@hotmail.com \\ ${ }^{2}$ Universidade Federal do Paraná, Curitiba, Paraná, Brasil - jwtraute@gmail.com*; o.sergio.costa@gmail.com \\ Recebido para publicação: 16/08/2017 - Aceito para publicação: 31/10/2017
}

\begin{abstract}
The aim of the work was to estimate trunk biomass in a Deciduous Seasonal Forest by using direct and indirect methods. The data were obtained from seven $12 \times 12 \mathrm{~m}$ plots, bringing to a total of 64 trees. Trunk biomass was determined by direct method and indirect methods which consisted of: 1) Real Volume (RV) of the trunk multiplied by the Weighted Average (WA) and Arithmetic Average (AA) of the specific basic mass of the wood species found, resulting in Real Volume for Weighted Average (RVWA) and Real Volume for Arithmetic Average (RVAA), and 2) by the Estimated Volume (EV) multiplied by WA and by AA, resulting in Estimated Volume for Weighted Average (EVWA) and Estimated Volume for Arithmetic Average (EVAA). The trunk biomass of the three plots determined by the direct method was $11,451 \mathrm{Kg}$. The indirect method that had the most similar to the real trunk biomass (TB) value result was the EVAA $(13,142 \mathrm{Kg})$, and the one that showed the largest difference was the RVWA, which was estimated at 20,061 Kg. The t-test showed significant difference of trunk biomass for indirect methods that used the RV; and the methods that used the EV did not differ statistically.

Keywords: Forest biomass; arboreal biomass; decidual stational forest.
\end{abstract}

\section{Resumo}

Estimativa da biomassa do fuste por diferentes métodos em floresta subtropical. O trabalho teve como objetivo estimar a biomassa do fuste em um fragmento de Floresta Estacional Decidual Montana utilizando métodos diretos e indiretos. Os dados de biomassa foram obtidos de sete parcelas de 12 x $12 \mathrm{~m}$, totalizando 64 árvores. A biomassa do fuste foi determinada pelo método direto e por métodos indiretos que consistiram em: $1^{\circ}$ ) Volume Rigoroso (VR) do fuste multiplicado pela Média Ponderada (MP) e Média Aritmética (MA) da massa específica básica da madeira das espécies encontradas, resultando em Volume Rigoroso para Média Ponderada (VRMP) e Volume Rigoroso para Média Aritmética (VRMA), e $2^{\circ}$ ) pelo Volume Estimado (VE) multiplicado pela MP e pela MA, resultando em Volume Estimado para Média Ponderada (VEMP) e Volume Estimado para a Média Aritmética (VEMA). O TB das três parcelas determinado diretamente foi de 11451 $\mathrm{Kg}$. O método indireto que mais se aproximou da biomassa do fuste foi o VEMA (13142 Kg), e o que apresentou a maior diferença foi o VRMP que totalizou $20061 \mathrm{Kg}$. O teste $\mathrm{t}$ indicou diferença significativa da biomassa do fuste para os métodos indiretos que utilizam o VR; e os métodos que utilizaram o VE não diferiram estatisticamente.

Palavras-chaves: Biomassa florestal; biomassa arbórea; Floresta Estacional Decidual.

\section{INTRODUCTION}

According to Ballantyne et al. (2012), climate changes are strongly influenced by emissions of greenhouse gases $(\mathrm{GHG})$, for example, carbon dioxide $\left(\mathrm{CO}_{2}\right)$. Estimations present that deforestation and degradation of native forests contribute with approximately $20 \%$ of the total $\mathrm{CO}_{2}$ emissions (ANGELSEN, 2009). However, if we consider the diversity of forest ecosystems, the quantification of carbon stocks and the potential of emissions represent one of the greatest challenges within a scenario of environmental changes.

In 2005, a discussion about projects of Reduced Emissions from Deforestation (RED) had started. These projects are currently a priority on the agenda of international negotiations and have evolved to Reduced Emissions from Deforestation and Forest Degradation (REDD). They represent an easy, inexpensive and quick way to reduce GHG emissions (ANGELSEN, 2008). REDD projects are substantiated by concession of financial incentives to preserve forests and maintain carbon stocks in forest ecosystems (TURNER et al., 2009). Despite 
the demand for projects and the need to quantify above-soil biomass accurately, there is still no consensus about the best methodology (direct and/or indirect) to estimate biomass in native forests (GATTO, 2011).

In the direct method approach (destructive), trees are felled and their components are separated and weighted. This method is time-consuming and costly, but it provides accurate information about biomass (LI; XIAO, 2007). By contrast, Brown et al. (1989) claimed that estimations generated from direct methods are unreliable due to the fact that they are based on few tendentious and small selected plots. Fearnside (1991) contested this criticism and observed that methods based on forest inventories (indirect) may be less biased, but the estimations fall short of the values obtained by direct methods.

The indirect method (non-destructive) estimates by means of allometric equations or biomass expansion factors, which are generated from data obtained via the direct method. Non-destructive estimations use variables of forest inventory such as Diameter at Breast Height (DBH), total height, and wood specific gravity (SG) without felling the trees (GATTO, 2011). Also, they are combined with regression models (BREUGEL et al., 2011). In such cases, biomass estimation is much cheaper and faster, but it tends to be less precise.

Knowledge of the average form factor of trees is indispensable for volume-based estimations. It presents variations depending on species, $\mathrm{DBH}$, age and site. By these means, form factor is the third most important variable, after diameter and height, in the determination of volume. Moreover, the basic wood density variable must also be included (FEARNSIDE, 1997).

In short, methods for biomass calculation in native forests still arouse controversy and produce mixed estimations. The working hypothesis is that different methods of biomass estimation generate significantly diverse results, even when the same database is used. In this context, the present study aims to measure trunk biomass of trees in a Deciduous Seasonal Forest fragment by using different methods in order to elucidate a few aspects of this controversy.

\section{MATERIALS AND METHODS}

The study was conducted in two areas: the first one is located in the municipality of Frederico Westphalen -RS (27 $23^{\prime} 40^{\prime \prime} \mathrm{S}$ and $53^{\circ} 26^{\prime} 10^{\prime \prime} \mathrm{W}$ at 530 meters above sea level) and the second, in the municipality of Iraí - RS $\left(27^{\circ} 13^{\prime} 35^{\prime \prime} \mathrm{S}\right.$ and $53^{\circ} 18^{\prime} 59^{\prime \prime}$ W at 240 meters above sea level) in the South Region of Brazil. This area represents a typical fragment of the Deciduous Seasonal Forest of primary succession that was changed by the selective logging of high commercial value species. Climate in the region is Humid Subtropical (cfa by Köppen Classification; well distributed rainfall regime and absence of marked dry season, with average annual precipitation between 1,700 and 1,900 mm (ROSSATO, 2014)). The soil is classified as Aluminum Ferric Red Oxisol (SANTOS et al., 2013).

Three sample units of $144 \mathrm{~m}^{2}$ were installed for data collection, which totaled $1008 \mathrm{~m}^{2}$, and were randomly distributed. Only trees with DBH above 10 centimeters were sampled. Since it is difficult to establish a parameter that indicates the mark in which the trunk starts to be considered a branch, we considered the morphological inversion point (MIP) as the maximum trunk height in this study.

Rigorous tree scaling was conducted in the field by the Smalian method; trees were measured at DBH and at $0,25,50,75$ and $100 \%$ MIP. The length of each section was also measured. Total trunk volume was calculated by the equation $v=g \times h \times f$ (eq. 01), in which $v=$ volume $\left(\mathrm{m}^{3}\right) ; g=$ basal area $($ at $\mathrm{DBH}) ; h=$ height of MIP (m); $f=$ form factor $(f=0.783)$.

Table 1. Form Factors for commercial height in different types of native forests of Atlantic forest.

Tabela 1. Fator de forma para altura comercial em diferentes tipologias florestais nativas do bioma Mata Atlântica.

\begin{tabular}{lll}
\hline Author & Form factor & Type of Forest and/or species \\
\hline SCOLFORO and MELLO (2006) & 0.825 & Semideciduous Stationary Forest, MG \\
COLPINI et al. (2009) & 0.742 & Open Ombrophylous Forest, northwest of MT. \\
\hline Average & 0.783 & \\
\hline
\end{tabular}

Basic density values for wood from each species were obtained from the literature (REITZ et al., 1988; MARCHIORI, 1997a; MARCHIORI, 1997b; MARCHIORI, 2000; LORENZI, 2014a; LORENZI, 2014b; MARCHIORI, 2007; RIBEIRO, 2009; PAULA; COSTA, 2011; TRAUTENMÜLLER et al., 2014); the values were determined for species from which density was not yet known. In order to determine the basic density of wood, discs of approximately two inches thickness at DBH were collected. They were labeled and divided into two symmetrically opposed wedges containing parts of heartwood and sapwood. Wooden wedges were submerged in water, where they remained until constant weight. Basic wood density was determined for each 


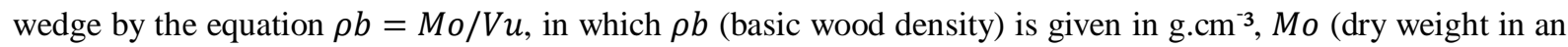
oven at $103^{\circ} \mathrm{C}$ ) in $\mathrm{g}$, and $\mathrm{Vu}$ (saturated volume) in $\mathrm{cm}^{-3}$. The green volume was obtained by the method of hydrostatic balance (TRAUTENMÜLLER et al, 2014).

Arithmetic average and weighted average were calculated through the volume of each tree. Trunk biomass was estimated by: 1) Real Volume (RV) x Arithmetic Average (AV) of SG; 2) Real Volume (RV) x Weighted Average (WA) of SG; 3) Estimated volume (EV) x Arithmetic average (AV); and 4) Estimated volume (EV) $x$ Weighted average (WA). These values were compared with trunk biomass (TB) that was determined in the field through the dissect method and were taken as a basis of comparison for the indirect methods.

The biomass analyses were performed by using five treatments (biomass estimation methods) of seven replicates (each field plot was considered as a replication). This characterizes dependence among the samples. Data were submitted to Shapiro-Wilk normality test, Bartlett test and paired t-test. All tests were performed with aid of R (R Development Core Team, 2017).

\section{RESULTS}

Sixty-four trees were sampled. Their average values for calculated basic wood density were $0.644 \mathrm{~g} . \mathrm{cm}^{-}$ ${ }^{3}$ for AV and $0.682 \mathrm{~g} . \mathrm{cm}^{-3}$ for WA, ranging from minimum of $0.303 \mathrm{~g} . \mathrm{cm}^{-3}$ (Erythrina falcata) to maximum of $0.905 \mathrm{~g} \mathrm{~cm}^{-3}$ (Eugenia rostrifolia) (Table 2). The value of WA was higher than the one of AV, since the formulation of AV considers the number of species. In the case of WA, volume is the most important. Therefore, large-sized trees and trees with high SG have greater influence on WA.

Table 2. Basic wood density $\left(\mathrm{g} . \mathrm{cm}^{-3}\right)$ for the evaluated species.

Tabela 2. Massa específica básica $\left(\mathrm{g} . \mathrm{cm}^{-3}\right)$ para as espécies estudadas.

\begin{tabular}{|c|c|c|c|c|c|c|c|c|}
\hline Species & & & Wood sp & cific grav & $\mathrm{y}\left(\mathrm{g}, \mathrm{cm}^{-3}\right)$ & & & Average \\
\hline Trichilia clausseni C.DC. & & $0.450^{2}$ & $0.450^{3}$ & & & & & 0.450 \\
\hline Trichilia catiguá A. Juss & & & & $0.700^{4}$ & $0.640^{5}$ & & & 0.670 \\
\hline Eugenia rostrifolia D. Legrand & $0.875^{1}$ & $0.935^{2}$ & & & & & & 0.905 \\
\hline Sorocea bonplandii (Baill.) W.C. Burger & & $0.550^{2}$ & $0.670^{3}$ & $0.769^{4}$ & $0.670^{5}$ & & & 0.665 \\
\hline $\begin{array}{l}\text { Chrysophyllum gonocarpum (Mart. \& } \\
\text { Eichler) Engl. }\end{array}$ & & & $0.700^{3}$ & & & & & 0.700 \\
\hline $\begin{array}{l}\text { Chrysophyllum marginatum (Hook. \& } \\
\text { Arn.) Radlk. }\end{array}$ & & & $0.780^{3}$ & & & & & 0.780 \\
\hline $\begin{array}{l}\text { Nectandra megapotamica (Spreng.) } \\
\text { Mez. }\end{array}$ & & $0.650^{2}$ & $0.650^{3}$ & $0.706^{4}$ & & & & 0.669 \\
\hline Cedrela fissilis Vell. & $0.550^{1}$ & & $0.550^{3}$ & & & & & 0.550 \\
\hline Campomanesia xanthocarpa O. Berg. & & & $0.650^{3}$ & $0.891^{4}$ & & & & 0.770 \\
\hline Machaerium stipitatum (DC.) Vogel & & $0.690^{2}$ & $0.840^{3}$ & & & & & 0.765 \\
\hline $\begin{array}{lll}\text { Syagrus } & \text { romanzoffiana } & \text { (Cham.) } \\
\text { Glassman } & & \end{array}$ & & & $0.650^{3}$ & & & & & 0.650 \\
\hline Erythrina falcata Benth. & $0.200^{1}$ & $0.390^{2}$ & $0.320^{3}$ & & & & & 0.303 \\
\hline Apuleia leiocarpa (Vogel) J. F. Macbr. & $0.875^{1}$ & $0.860^{2}$ & $0.830^{3}$ & $0.989^{4}$ & & & & 0.888 \\
\hline Parapiptadenia rígida (Benth.) Brenan & $0.875^{1}$ & $0.920^{2}$ & $0.850^{3}$ & & & & & 0.882 \\
\hline Guarea macrophylla Vahl. & & & & & $0.520^{5}$ & & & 0.520 \\
\hline Cordia ecalyculata Vell. & & & $0.650^{3}$ & $0.888^{4}$ & & & & 0.769 \\
\hline $\begin{array}{l}\text { Tetrorchidium rubrivenium Poepp. \& } \\
\text { Endl. }\end{array}$ & $0.500^{1}$ & & & & & & & 0.500 \\
\hline Alchornea sidifolia Müll. Arg. & & $0.450^{2}$ & & & & & & 0.450 \\
\hline Myrocarpus frondosus Allemão & $0.900^{1}$ & $0.880^{2}$ & $0.910^{3}$ & & & & & 0.897 \\
\hline Picrasma crenata (Vell.) Engl. & & & & & & & & \\
\hline Casearia sylvestris $\mathrm{Sw}$. & & & $0.840^{3}$ & & & & & 0.840 \\
\hline Tabebuia cassiniodes Lam. & & & $0.390^{3}$ & $0.440^{4}$ & & & & 0.415 \\
\hline $\begin{array}{l}\text { Cordia americana (L.) Gottshling \& J.E. } \\
\text { Mill }\end{array}$ & & & & & & $0.629^{6}$ & & 0.629 \\
\hline $\begin{array}{l}\text { Alchornea triplinervia (S.) Müller } \\
\text { Argoviensis }\end{array}$ & & & & & & $0.335^{6}$ & & 0.335 \\
\hline $\begin{array}{l}\text { Balfourodendron riedelianum (Engl.) } \\
\text { Engl. }\end{array}$ & & & & & & & $0.697^{7}$ & 0.697 \\
\hline Calyptranthes tricona D.Legrand & & & & & & & $0.736^{7}$ & 0.736 \\
\hline Ficus guaranitica Chodat \& Vischer & & & & & & & $0.330^{7}$ & 0.330 \\
\hline
\end{tabular}

FLORESTA, Curitiba, PR, v. 47, n. 4, p.553 - 560, out. / dez. 2017.

Balbinot, R. et al.

ISSN eletrônico 1982-4688

DOI: $10.5380 /$ rf.v47i4.54574 
Source: ${ }^{1}$ REITZ et al. (1988); ${ }^{2}$ MARCHIORI (1997a), MARCHIORI (1997b), MARCHIORI (2000), MARCHIORI (2007); ${ }^{3}$ LORENZI (2014a), LORENZI (2014b); ${ }^{4}$ PAULA and COSTA (2011); ${ }^{5}$ RIBEIRO (2009); ${ }^{6}$ TRAUTENMÜLLER et al. (2014); ${ }^{7}$ Author's data. For Picrasma crenata, specific gravity was not found in the literature; thus the average value of the other species was used.

Shapiro-Wilk test demonstrated normally distributed samples $(\mathrm{W}=0.950)$. Bartlett's test accepted the homogeneity hypothesis among the averages of the observed biomass. t-test showed no statistical difference between the weight by estimated volume and the specific mass arithmetic average (EVAA), and the weight by estimated volume and the specific mass weighted average (EVWA), when compared to TB. However, the relations of the weight by real volume and the specific mass arithmetic average (RVAA) and the weight by real volume and the specific mass weighted average (RVWA) revealed significant difference $(\mathrm{p}<0.05)$.

The calculated volumes were $29.38 \mathrm{~m}^{3}$ for RV and $20.42 \mathrm{~m}^{3}$ for EV (eq. 01). The calculated weight for MIP was 20.06 and $18.91 \mathrm{Mg}$ for RVWA and RVAA, and 13.94 and 13.14 Mg for EVWA and EVAA, respectively. TB determined in the field was $11.45 \mathrm{Mg}$. Values for the summation of the three plots are presented on table 3.

Table 3. Results for trunk biomass of each plot, treatment and statistical analysis by the t test.

Tabela 3. Resultados da biomassa do tronco de cada parcela, tratamento e análise estatística através do teste t.

\begin{tabular}{|c|c|c|c|c|c|c|c|c|c|}
\hline \multirow{2}{*}{ SU } & \multicolumn{2}{|c|}{ Volume } & \multicolumn{5}{|c|}{ Treatment } & \multirow{2}{*}{ CV $(\%)$} & \multirow{2}{*}{$\mathbf{R}^{2}$} \\
\hline & Real & Eq. 01 & TB & WEVAV & WEVWA & WRVAV & WRVWA & & \\
\hline 1 & 8.19 & 5.81 & 2860.46 & 3721.19 & 4228.28 & 5242.97 & 5957.43 & & \\
\hline 2 & 5.24 & 3.32 & 2704.33 & 2122.30 & 2411.51 & 3355.81 & 3813.11 & & \\
\hline 3 & 5.14 & 3.35 & 2212.73 & 2145.49 & 2437.85 & 3289.99 & 3738.26 & & \\
\hline 4 & 1.43 & 1.19 & 378.21 & 764.35 & 810.68 & 918.56 & 974.24 & & \\
\hline 5 & 1.54 & 1.11 & 711.14 & 717.38 & 760.87 & 989.36 & 1049.34 & & \\
\hline 6 & 3.70 & 3.15 & 1466.64 & 2030.86 & 2056.42 & 2381.11 & 2420.81 & & \\
\hline 7 & 6.34 & 4.52 & 2032.09 & 2908.91 & 3085.23 & 4078.71 & 4325.95 & & \\
\hline Sum & 31.57 & 22.46 & 11450.90 & 13141.46 & 13938.04 & 18914.24 & 20060.73 & & \\
\hline Averages* (UA) & 4.51 & 3.21 & $1635.8 \mathrm{a}^{*}$ & $1877.4 \mathrm{a}$ & $1991.1 \mathrm{a}$ & $2702.0 \mathrm{~b}$ & $2865.8 \mathrm{~b}$ & 17.21 & 0.93 \\
\hline
\end{tabular}

Sample units (SU); real volume and basic specific mass weighted average (RVWA); real volume and basic specific mass arithmetic average (RVAA); estimated volume and specific mass weighted average (EVWA); estimated volume e specific mass arithmetic average (EVAA); trunk biomass (TB); Coefficient of variation (CV); Coefficient of linear determination $\left(\mathrm{R}^{2}\right)$. * Means followed by the same letters do not differ significantly $(5 \%)$.

\section{DISCUSSION}

Values of SG calculated for the species from the Deciduous Seasonal Forest (both for AV, 0.649 g.cm ${ }^{-3}$, and for WA, $0.682 \mathrm{~g} . \mathrm{cm}^{-3}$ ) are close to the values found by other authors for subtropical and tropical forests (Table 3). However, a wide variation in the values of basic wood density is found. For example, when studying 90 species in tropical forests, Muller-Landau (2004) found values between 0.12 and 1.05 g.cm ${ }^{-3}$ for different sites located in the same type of forest. The results (Table 4) show that estimations that use basic wood density as one of the variables might lead to error in the calculations of biomass, above-soil biomass and carbon.

Table 4. Arithmetic average (AV) and weighted average (WA) for wood specific gravity in different forest ecosystems $\left(\mathrm{g} \cdot \mathrm{cm}^{-3}\right)$.

Tabela 4. Média aritmética (MA) e média ponderada (MP) da massa específica básica da madeira em diferentes ecossistemas florestais $\left(\mathrm{g} . \mathrm{cm}^{-3}\right)$.

\begin{tabular}{llll}
\hline Source & Type of Forest & AV $\left(\mathrm{g}^{\mathrm{cm}}{ }^{-3}\right)$ & WA $\left(\mathrm{g} . \mathrm{cm}^{-3}\right)$ \\
\hline Ribeiro et al. (2010) & Semidecidual Stational Forest & 0.65 \\
Fearnside (1997) & Montane Forest in the city of Viçosa-MG. & 0.69 \\
Ribeiro et al. (2009) & Amazon Rainforest. & 0.65 & 0.70 \\
\hline
\end{tabular}




\begin{tabular}{lll}
\hline & Montane & \\
& Four different places, Biological Station La Selva in & \\
Muller-Landau (2004) & Costa Rica, Colorado Island Neighborhood in & $0.47-0.72$ \\
& $\begin{array}{l}\text { Panamá, Biological Station Cocha Cashu in Peru and } \\
\text { Manaus, Brazil. }\end{array}$ & \\
& $\begin{array}{l}\text { Tropical Forest in Boi Tano Forest Reserve, in West } \\
\text { Henry et al. (2010) }\end{array}$ & $\begin{array}{l}0 \\
\text { Gana. }\end{array}$ \\
Alvarez et al. (2012) & Tropical Forest in Colombia & 0.58 \\
\hline
\end{tabular}

Variations of basic wood density in forest species occur due to the differences in the anatomic structure of the wood and to the quantity of extractive substances in each individual. These alterations occur on the basis of tree age, genotype, site quality, climate, geographic location and growth rate (TREVISAN et al., 2012). In addition, trunk irregularities, such as the occurrence of emptiness and rotting associated with age difference among individuals (MULLER-LANDAU, 2004) and senescent trees, cause a variation in the SG as well as in the real volume of the trunk.

As for trunk volume, EV (eq 01) underestimates the wood volume of the trunk. This difference can be partly explained by the variation in trunk forms of trees depending on species, site, age, genetic aspects, sanity, etc. According to Machado and Figueiredo Filho (2003), studies about trunk forms were directed at trees that could be considered as regulars, i.e., that could be compared to defined geometric figures. However, current studies that try to estimate biomass stockpile need to consider all the trunks, regardless of species, site, sanity, genetics, age, etc. Based on that, research on biomass evaluation techniques is needed.

The results confirm the considerations of Fearnside (1991) regarding direct methods that affirm that indirect methods overestimate the real weight of trunks. There is clear disagreement on biomass estimations, which can create overestimation of $75.2 \%$ in the case of WRVWA. TB considers every variation of SG in radial, tangential and longitudinal directions and the presence or absence of hollow trunks at the initial stage of rotting. By contrast, indirect methods do not consider this variation; only volume and SG.

Methods that use the WA of SG tend to increase this error when compared to the use of AV, since WA attributes greater importance to trunks of higher volume. Trunks of higher volumes belong to older trees, which are more likely to present emptiness and rotting consequently. Accordingly, trees of large diameters must be carefully analyzed when using both direct and indirect methods, because few individuals might represent a large part of the biomass of a forest ecosystem (in this case, more than 50\%).

\section{CONCLUSION}

- The direct method is the most effective way to quantify trunk biomass because it assimilates all the variations.

- Indirect methods that use estimated volume did not differ statistically for trunk biomass; and indirect methods that use real volume presented significant differences for trunk biomass.

\section{ACKNOWLEDGEMENTS}

The authors are thankful for the financial support to this project from the State of Rio Grande do Sul through the Foundation for Research Support of the State of Rio Grande do Sul - FAPERGS, process 10/0164-5 and 10/1818-5. We would also like to thank CAPES (Coordination for the Improvement of Higher Educational Personnel) for the master's degree scholarship.

\section{REFERENCES}

ALVAREZ, E.; DUQUE, A.; SALDARRIAGA, J.; CABRERA, K.; SAlAS, G.; VAlLE, I.; LEMA, A.; MORENO, F.; ORREGO, S.; RODRÍGEZ, L. Tree above-ground biomass allometries for carbon stocks estimation in the natural forests of Colombia. Forest Ecology and Management, Amsterdam, v. 267, p. 297308, 2012.

ANGELSEN, A. (ed,). Moving ahead with REDD: Issues, Options, and Implications. CIFOR: Bogor, Indonesia, 2008, $172 \mathrm{p}$.

ANGELSEN, A. (ed,). Realising REDD+: national strategy and policy options. CIFOR, Bogor, Indonesia, 2009, $362 \mathrm{p}$.

FLORESTA, Curitiba, PR, v. 47, n. 4, p.553 - 560, out. / dez. 2017.

Balbinot, R. et al.

ISSN eletrônico 1982-4688

DOI: $10.5380 /$ rf.v47i4.54574 
BALlAnTYNE, A. P.; ALDEN, C. B.; MILLER, J. B.; TANS, P. P.; WHITE, J. W. C. Increase in observed net carbon dioxide uptake by land and oceans during the last 50 years. Nature, v. 488, p. 70-72. 2012

BREUGEL, M.; RANSIJIN, J.; CRAVEN, D.; BONGERS, F.; HALL, J. S. Estimating carbon stock in secondary forests: Decisions and uncertainties associated with allometric biomass models. Forest Ecology and Management, Amsterdam, v. 262, p. 1648-1657, 2011.

BROWN, S.; GILlESPIE, A. J. R.; LUGO, A. E. Biomass estimation methods for tropical forests with applications to forest inventory data. Forest Science, v. 35, p. 881-902, 1989.

COLPINI, C.; TRAVAGIN, D. P.; SOARES, T. S.; SILVA, V. S. M. Determinação do volume, do fator de forma e da porcentagem de casca de árvores individuais em uma Floresta Ombrófila Aberta na região noroeste de Mato Grosso. Acta Amazonica, v. 39, n. 1, p. 97-104, 2009.

FEARNSIDE, P. M.; Greenhouse gas contributions from deforestation in Brazilian Amazonia. In: LEVINE, J,S, (Ed,) Global Biomass Burning: Atmospheric Climatic and Biospheric Implications, Boston: MIT, p. 92-105, 1991.

FEARNSIDE, P. M. Wood density for estimating forest biomass in Brazilian Amazonia. Forest Ecology and Management, Amsterdam, v. 90, n. 1-3, p. 59-87, 1997.

GATTO, A.; BARROS, N. F.; NOVAIS, R. F.; SILVA, I. R.; LEITE, H. G.; VILlANI, E. M. Estoque de carbono na biomassa de plantações de eucalipto na Região centro-leste do estado de minas gerais, Minas gerais. Revista Árvore, Viçosa, v. 35, n. 4, p. 895-905, 2011.

HENRY, M.; BESNARD, A.; ASANTE, W. A.; ESHUN, J.; ADU-BREDU, S.; VALENTINI, R.; BERNOUX, M.; SAINT-ANDRÉ, L. Wood density, phytomass variations within and among trees, and allometric equations in a tropical rainforest of Africa. Forest Ecology and Management, Amsterdam, v. 260, p.1375-1388, 2010.

LI, C. P.; XIAO, C. W. Above- and belowground biomass of Artemisia ordosica communities in three contrasting habitats of the Mu Us desert, northern China. Journal of Arid Environments, v. 70, n. 2, p. 195207, 2007.

LORENZI, H. Árvores brasileiras: manual de identificação e cultivo de plantas arbóreas nativas do Brasil. $4^{\mathrm{a}}$, Ed, Nova Odessa, São Paulo: Instituto Plantarum, 2014a, v.1, 368 p.

LORENZI, H. Árvores brasileiras: manual de identificação e cultivo de plantas arbóreas nativas do Brasil. $2^{\mathrm{a}}$, Ed, Nova Odessa, São Paulo: Instituto Plantarum, 2014b, v.2, 384 p.

MACHADO, S. A.; FIGUEREIDO FILHO, A. Dendrometria. UFPR, 2003. 309 p.

MARCHIORI, J. N. C.; SOBRAL, M. Dendrologia das angiospermas: myrtales. Santa Maria, Ed, da UFSM, 1997a, 304 p.

MARCHIORI, J. N. C. Dendrologia das angiospermas: das magnoliáceas as flacurtiáceas. Santa Maria, Ed, da UFSM, 1997b, $271 \mathrm{p}$.

MARCHIORI, J. N. C. Dendrologia das angiospermas: das bixáceas as rosáseas. Santa Maria, Editora UFSM, 2000, 240 p.

MARCHIORI, J. N. C. Dendrologia das angiospermas: leguminosas. Santa Maria, Ed, da UFSM, 2007, 199 p.

MULLER-LANDAU, H. C. Interspecific and Inter-site Variation in Wood Specific Gravity of Tropical Trees. Biotropica, v. 36, n. 1, p. 20-32, 2004.

PAUlA, J. E.; COSTA, K. P. Densidade da madeira de 932 espécies nativas do brasil. Porto Alegre, ed, Cinco Continentes, 2011, 248 p.

R Development Core Team. R: A language and environment for statistical computing. R Foundation for Statistical Computing. Vienna, Austria. 2017.

REITZ, R.; KLEIN, R. M.; REIS, A. Projeto madeira do Rio Grande do Sul. Porto Alegre: CORAG, 1988, $525 \mathrm{p}$.

RIBEIRO, S. C.; JACOVINE, L. A. G.; SOARES, C. P. B.; MARTINS, S. V.; NARDELLI, A. M. B.; DE SOUZA, A. L. Quantificação de biomassa e estimativa de estoque de carbono em uma capoeira da zona da mata mineira. Revista Árvore, v. 34, n. 3, p. 495-504, 2010. 
RIBEIRO, S. C.; JACOVINE, L. A. G.; SOARES, C. P. B.; MARTINS, S. V.; DE SOUZA, A. L. Quantificação de biomassa e estimativa de estoque de Carbono em uma floresta madura no município de viçosa. Minas gerais, Revista Árvore, v. 33, n. 5, p. 917-926, 2009.

ROSSATO, M. S. Os climas do Rio Grande do Sul: Tendências e tipologias. In: MENDONÇA, F. (Org.). Os climas do Sul: Em tempos de mudanças climáticas globais. Jundiaí: Paco Editorial, 2014. p. 217-271.

SANTOS, H. G.; JACOMINE, P. K. T.; ANJOS, L. H. C.; OLIVEIRA, V. A.; LUBRERAS, J. F.; COELHO, M. R.; ALMEIDA, J. A.; CUNHA, T. J. F.; OLIVEIRA, J. B. Sistema Brasileiro de Classificação de Solos. $3^{\mathrm{a}}$ ed. Brasília, EMBRAPA, 353 p, 2013.

SCOLFORO, J. R. S.; MELLO, J. M. Inventário Florestal. Lavras, 2006, 561 p.

TRAUTENMÜLlER, J. W.; BALBINOT, R.; BORELLA， J.; TREVISAN， R.; BALESTRIN， D.; VENDRUSCOLO, R.; SABADINI, A. M. Variação longitudinal da massa específica básica da madeira de Cordia americana e Alchornea triplinervia. Ciência Rural, v. 44, n. 5, p. 817-821, 2014.

TREVISAN, R.; DENARDI, L.; HASELEIN, C. R.; GATTO, D. A. Efeito do desbaste e variação longitudinal da massa específica básica da madeira de Eucalyptus grandis. Scientia Forestalis, v. 40, n. 95, p. 393-399, 2012.

TURNER, W. R.; OPPENHEIMER, M.; WILCOVE, D. S. A force to fight global warming. Nature, v. 462, p. 278-279, 2009.

FLOREST A, Curitiba, PR, v. 47, n. 4, p.553 - 560, out. / dez. 2017. 
FLORESTA, Curitiba, PR, v. 47, n. 4, p. 553 - 560, out/dez.. 2017. 